\title{
Integrative Application of Phosphorein and Microbein Improves Vicia faba (L.) Performance and Controls Soil-borne Diseases
}

\author{
Ayman H. A. Mahdi ${ }^{1 *}$, Mostafa M. Rady² and Gomaa A. Abd El-Wahed ${ }^{3}$ \\ ${ }^{I}$ Department of Agronomy, Faculty of Agriculture, Beni-suef University, \\ Beni-suef 62521, Egypt \\ ${ }^{2}$ Departmen of Botany, Faculty of Agriculture, Fayoum University, Fayoum 63514, Egypt \\ ${ }^{3}$ Plant Pathology Research Institute, Agricultural Research Center, Giza 12619, Egypt \\ *Corresponding author
}

\section{A B S T R A C T}

\begin{tabular}{|l|}
\hline Ke y w o r d s \\
Faba bean varieties, \\
Productivity, \\
Phosphorein, \\
Microbein, \\
Damping-off, Root- \\
rot disease
\end{tabular}

\section{Introduction}

Faba bean (Vicia faba L.) is a popular legume consumed worldwide as an important protein source for human and animal nutrition. Its seeds are also rich in carbohydrates, minerals, biotic stress conditions.
Plants are constantly exposed to biotic stresses, which cause changes in plant metabolism including physiological damages, leading to crop productivity losses. This study was conducted to investigate bio-fertilizer applications (i.e., phosphorein, microbein, and combination of them at a ratio of 1:1 for seed before sowing) influences on two varieties (i.e., Giza 429 and Giza 40) of Vicia faba (L.) plant performances on borne diseasesinfected soil. Growth, yield and its quality, physio-biochemical attributes, nutrient contents and disease assessment were investigated. Combined phosphorein and microbein treatment significantly increased all plant growth characteristics, leaf photosynthetic pigments, all physio-biochemical attributes, and nutrients contents compared to individual phosphorein or microbein application, which in turn significantly exceeded the control (seed without bio-fertilizers). All these improved parameters significantly reflected in highest yield and its components with the phosphorein+microbe in application. In contrast, $\mathrm{Na}^{+}$content along with percentages of damping-off and root-rot incidence, as well as disease severity were significantly decreased compared to individual treatments and the control. Data of the present study also show that, variety of Giza 429 recorded better results than variety of Giza 40, concluding that Giza 429 was more soil borne disease-tolerant. Results of the current study are important as the potential of combined phosphorein+microbein application to suppress soil-borne diseases and enhance faba bean performance under this 
serious biotic stresses that challenge both horizontal and vertical expansion of faba beans. Fungi such as Rhizoctonia solani, Fusarium solani, Macrophomina phaseolina, Alternaria alternata, and $F$. moniliforme are considered as the most serious biotic stress, restricting faba bean productions (Abd El-Ati and El-Hadidy 2013). In Egypt, soil-borne diseases, specifically damping-off and root-rot diseases are increased due to the continuous cultivation in the same soil areas for long periods, shortage of high yielding disease resistant-varieties, lack of proper development or technology for growing and harvesting of faba beans, and scarcity of researchers concerned to present situation and practical strategies for disease management. Use of resistant faba bean varieties has been suggested for the disease management (Habtegebriel and Boydom 2016). Therefore, it is necessary to assess the differences among crop varieties for their resistance mechanisms through determining their performances under biotic; disease stress.

Bio-fertilizers are known as microbial inoculants that consist of artificially multiplied cultures of certain soil organisms, which can strengthen seed germination and improve soil fertility and crop productivity. Bio-fertilizers are proved to add nutrients through the natural processes of nitrogen fixation, solubilizing phosphorus, and induce plant growth through synthesizing many growth-promoting substances (Taha et al., 2016). Phosphorein and microbein are used as bio-fertilizers, especially for legumes because they are more effective in supplying legume plants with nitrogen and phosphorus compared to the conventional chemical fertilization. Microbein has greater amounts of symbiotic and nonsymbiotic bacteria which are responsible for $\mathrm{N}$ fixation. Inoculation of faba bean seeds with such bacteria led to an increase in the availability of various nutrients that positively reflected in growth, yield and its quality (Abo
El-Soud et al., 2003). On the other hand, soil inoculation with phosphorein, known as phosphate dissolving bacteria, has been reported to improve soil fertility and plant productivity. Application of phosphorein with or without minerals markedly increased the available $\mathrm{P}$ in soil and its uptake by plants and subsequently increased plant growth and its yield on sandy loam (Mohammed 2004) or calcareous soil (Saber et al., 1983). It has also been reported that inoculation of faba bean plants with phosphorein significantly increased plant weight compared to the untreated plants (Eman et al., 1993).

Soil-borne diseases as one of the biotic stresses can be bio-controlled. Pseudomonas aeruginosa has been reported to counter biotic stresses (Pandey et al., 2012). Bacillus subtilis N11 in addition to mature composts has been reported to control Fusarium infestation on banana roots (Zhang et al., 2011) and $B$. subtilis (UFLA285) has been reported to provide resistance against Rhizoctonia solani (Medeiros et al., 2011). In addition, Paenibacillus polymyxa (SQR-21) has been identified as a potential agent for bio-control of Fusarium wilt in watermelon (Ling et al., 2011). It has been shown, in some cases, that mycorrhizae can confer along with bacteria resistance against fungal pathogens and inhibit the growth of many root pathogens such as $R$. solani, Pythium spp., F. Oxysporum, A. obscura and $H$. annosum (Khalil and Labuschagne 2002; Riedlinger et al., 2006) by improving plant nutrients profile and thereby productivity (Ansari et al., 2013). For example, Glomus mosseae has been effective against Fusarium oxysporum f. sp. Basilica that causes root-rot disease in basil plants (Toussaint et al., 2008). Further, Medicago tranculata has been conferred an induction of various defense-related genes with mycorrhizal colonization (Liu et al., 2007). It has been reported that addition of Pseudomonas fluorescens in addition to 
arbuscular mycorrhizal fungi to the soil can decrease the pathogenic development of rootrot and enhance Phaseolus vulgaris (L.) yield (Neeraj 2011).

Based on the abovementioned, the aim of this study was to evaluate the soil-borne diseases resistance of two faba bean varieties (Giza 429 and Giza 40) by seed inoculation with some bio-fertilizers such as phosphorein and microbein (especially the combination of them at a ratio of $1: 1$ ) on borne diseases-infected soil. To support this evaluated parameter (disease tolerance), faba bean growth and productivity, as well as physio-biochemical attributes and nutrients contents were also assessed.

\section{Materials and Methods}

\section{Plant material, growing conditions, experimental design and treatments}

Two field experiments were conducted at the Experimental Farm of the Faculty of Agriculture, Fayoum University, Egypt during the two successive winter seasons of $2017 / 2018$ and $2018 / 2019$ to investigate the effect of two bio-fertilizers; phosphorein and microbein applied for inoculation of seeds individually or in combination (at a ratio of 1:1) on soil borne diseases suppression and enhancement of growth and productivity of two faba bean varieties (i.e., Giza-429 and Giza-40) grown under the conditions of borne disease-infected soil. Phosphorein was contained live cells of efficient bacteria strains as phosphate dissolving bacteria (Bacillus megatherium). Microbein was contained live cells of efficient bacterial strains of $\mathrm{N}$-fixing bacteria (Azotobacter chroccocum, Azospirillum braselence, Pseudomonas sp., Rhisobium sp., and Bacillus megaterium). Both bio-fertilizers were prepared in the laboratory of Microbiology and Biotechnology Department, Faculty of Agriculture, Fayoum
University, Fayoum, Egypt. They were used at the rate of $700 \mathrm{~g}$ phosphorein or microbein per $100 \mathrm{~kg}$ seeds for the individual inoculations and $350 \mathrm{~g}$ phosphorein $+350 \mathrm{~g}$ microbin per $100 \mathrm{~kg}$ seeds for combination inoculation. Arabic gum (16\%) was used as a sticking agent.

To test soil infection, diseases survey was conducted on 2016/2017 and 2017/2018 seasons for percentages of infected 2 and 4 months old faba bean plants. Disease syndrome, i.e. withering, discoloration or yellowing, stunting, wilting, rotted roots occurred on plants growing under field conditions were recorded in (Table 2). Damping-off and root-rot diseases were always found in all plantations examined in the surveyed soil. Samples from infected plants were collected for isolation trials in laboratory.

The experimental design was split plot arrangement in randomized complete blocks design with three replications, where varieties were allotted to the main plots, while biofertilizers were arranged in the sub plots. Healthy seeds of two varieties (i.e., Giza 429 and Giza 40) of faba bean ( $V$. faba L.) were sown on 17 and 21 October 2017 and 2018, respectively. Seeds were obtained from Legumes Crop Research Department, Field Crop Research Institute, Agricultural Research Centre, Giza, Egypt and were selected for uniformity by choosing those of equal size and of the same colour. The selected seeds were washed with distilled water, sterilized in $1 \%$ (v/v) sodium hypochlorite for approx. $2 \mathrm{~min}$, washed thoroughly again with distilled water, and left to dry at room temperature. Seeds were subjected to inoculation treatments with phosphorein (Phrn), microbein (Mibn) or distilled water (as a control) for $4 \mathrm{~h}$, and then soaked seeds were air-dried again at room temperature overnight. Uniform, air-dried faba bean seeds were sown in hills spaced 20-25 
$\mathrm{cm}$ apart, in rows spaced $70 \mathrm{~cm}$ apart in $3.0 \mathrm{~m}$ $\times 3.5 \mathrm{~m}$ plots, using an equivalent of $120 \mathrm{~kg}$ seed $\mathrm{ha}^{-1}$ to generate the recommended planting density. Thinning was done before the first irrigation to remain two plants per hill.

During soil preparation and plant growth, the soil was supplemented with the full dose of NPK fertilizer according to the recommendations of the Ministry of Agriculture and Land Reclamation. These recommendations were for $360 \mathrm{~kg} \mathrm{ha}^{-1}$ calcium superphosphate $\left(15.5 \% \mathrm{P}_{2} \mathrm{O}_{5}\right), 240 \mathrm{~kg}$ $\mathrm{ha}^{-1}$ ammonium sulfate $(20.5 \% \mathrm{~N})$ and $120 \mathrm{~kg}$ $\mathrm{ha}^{-1}$ potassium sulfate $\left(48 \% \mathrm{~K}_{2} \mathrm{O}\right)$. Irrigation water was added to $100 \%$ of the reference crop evapotranspiration (ETo), values from the Fayoum Meteo Station. Seven irrigations were applied in each season, with total water rates of about $2800 \mathrm{~m}^{3} \mathrm{ha}^{-1}$ in each growing season. All other recommended agricultural practices were followed as recommended by the Ministry of Agriculture and Land Reclamation. Soil samples were taken at the two depths of 30 and $60 \mathrm{~cm}$ for mechanical and chemical analyses as described by Chapman and Pratt (1978), and data are presented in (Table 1).

\section{Disease assessment}

To isolate and identify damping-off and rootrot causal organisms, faba bean plants with symptoms of root-rot infection were collected in plastic bags from the field a year before the experiment and brought to the laboratory. The infected samples were rinsed in tap water and the necrotic portions were excised and cut into at least $2 \mathrm{~mm}$, then surface sterilized with $5 \%$ sodium hypochlorite $(\mathrm{NaClO})$ for $30 \mathrm{~s}$ and rinsed in 4 successive changes of sterile distilled water. These were then plated on potato dextrose agar (PDA) and incubated at $25 \pm 2{ }^{\circ} \mathrm{C}$ for up to 5 days under $12 \mathrm{hr}$ photoperiod. Hyphal type transfer and the single spore technique were adopted whenever possible. Pure cultures and morphological features were done referring to Gilman (1957), Burnett and Hunter (1972) and Nelson et al., (1983). The disease assessment was performed periodically by examining and recording damping off after 30 and 45 days from sowing date. Percentage of root-rot disease incidence was assessed 30 days after sowing.

Disease severity (DS) was estimated visually by assessing the necrotic regions on the roots and hypocotyls using rating scale of $0-5$ as described by Filion et al., (2003).

$\mathrm{DS}=[\Sigma(\mathrm{ab}) / \mathrm{AK}] \times 100$

Where "a" is the number of diseased plants having the same degree of infection, "b" is the degree of infection, "A" is the total number of examined plants, and " $\mathrm{K}$ " is the highest degree of infection.

\section{Plant growth and yield measurements}

From each experimental plot, Fifty-day-old plants $(n=10)$ were carefully removed and dipped in a bucket of water. Plants were shaken gently to remove all adhering soil particles and the lengths of their shoots were measured using a meter scale. Numbers of branches plants ${ }^{-1}$ were counted. Using a graph sheet, leaf area per plant was measured manually where the squares covered by the leaf were counted. Plant shoots were weighed for fresh weights and were then placed in an oven at $70{ }^{\circ} \mathrm{C}$ until constant weight and the dry weights were recorded.

At the end of each experiment ( 3 and 5 April 2018 and 2019, respectively) for dry yield, all pods on each plant of each experimental plot were collected to air-dry and they were then counted. The seeds in all pods were extracted and weighed to calculate average 100-dry seed weight, and dry seed yield plant ${ }^{-1}$ and $\mathrm{ha}^{-1}$. 
Determination of relative water content and membrane stability index, and the contents of total soluble sugars, free proline, and protein

RWC [according to the method of Osman and Rady (2014)] and MSI [as described in the method of Rady (2011)] were assessed using fresh fully-expanded leaves excluding the midribs. The following equations were used for calculating both RWC and MSI:

RWC $(\%)=[(F M-D M) \div(T M-D M)] \times$ 100

$\operatorname{MSI}(\%)=\left[1-\left(\mathrm{C}_{1} \div \mathrm{C}_{2}\right)\right] \times 100$

Free proline content $\left(\mathrm{mg} \mathrm{g}^{-1} \mathrm{DW}\right)$ in dried faba bean leaves was measured using the Bates et al., (1973) method using 3\% (v/v) sulphosalicylic acid for plant material extraction and freshly prepared acid-ninhydrin solution and toluene for separating the upper toluene phase to read on $520 \mathrm{~nm}$ using a UV160A UV-visible spectrophotometer (Shimadzu, Kyoto, Japan), and the content of proline in each sample was determined using a standard curve based on analytical-grade proline. Total soluble sugars content $\left(\mathrm{mg} \mathrm{g}^{-1}\right.$ DW) was determined according to Irigoyen et al., (1992) method using 96\% (v/v) ethanol for extraction and freshly-prepared anthrone reagent [150 mg anthrone plus $100 \mathrm{ml}$ of $72 \%$ (v/v) sulphuric acid], and reading was performed on $625 \mathrm{~nm}$ using a UV-160A UVvisible spectrophotometer (Shimadzu, Kyoto, Japan). Determination of total nitrogen $(\mathrm{N})$ in seeds was carried out with Micro-Kjeldahl method (A.O.A.C. 1995). Using total $\mathrm{N}$ content, protein was calculated by multiplying total $\mathrm{N}$ by a factor of 6.25 .

\section{Determination of leaf photosynthetic pigment contents}

The photosynthetic pigments (i.e., chlorophyll "a", chlorophyll "b" and total carotenoids in mg $\mathrm{g}^{-1} \mathrm{FW}$ ) were estimated by the spectrophotometric method recommended by Lichtenthaler (1987). Leaf samples (0.2 g from each replicate of each treatment $(n=10)$ were homogenized in $50 \mathrm{ml} 80 \%$ (v/v) acetone and centrifuged at $10,000 \times \mathrm{g}$ for $10 \mathrm{~min}$. The absorbance of each acetone-extracted sample was measured at 665,649 , and $440 \mathrm{~nm}$ using a UV-160A UV-visible spectrophotometer (Shimadzu, Kyoto, Japan).

Determination of leaf nitrogen $(\mathrm{N})$, phosphorus (P), potassium (K), calcium (Ca) and sodium (Na) contents

Leaf $\mathrm{N}$ and $\mathrm{P}\left(\mathrm{mg} \mathrm{g}^{-1} \mathrm{DW}\right)$ were determined according to A.O.A.C. (1995) and Jackson (1967), respectively. After digesting the leaf samples using perchloric and sulfuric acids at a ratio of $1: 3, \mathrm{~K}^{+}$and $\mathrm{Na}^{+}$ion contents (in $\mathrm{mg}$ $\left.\mathrm{g}^{-1} \mathrm{DW}\right)$ were assessed using a PerkinElmer Model 52-A Flame Photometer (Glenbrook, Stamford, CT, USA; Page et al., 1982). Leaf $\mathrm{Ca}^{2+}$ content was determined using a PerkinElmer Model 3300 Atomic Absorption Spectrophotometer (Chapman and Pratt 1978).

\section{Statistical analysis}

All data of the present study were subjected to analysis of variance (ANOVA) for a split-plot arrangement in randomized complete blocks design, after testing for homogeneity of error variances as described in the methods of Gomez and Gomez (1984). Combined analysis of data for the two seasons was performed and significant differences between each two treatments were compared at $P \leq 0.05$ by the Duncan's Multiple Range Test.

\section{Results and Discussion}

\section{Pathogenicity tests of faba bean varieties}

Samples of both faba bean varieties (i.e., Giza 429 and Giza 40) used for fungi isolation and identification showed clear symptoms of root- 
rot, and its percentage was recorded. Data in Figure 1 show that Rhizoctonia solani was the dominant pathogen occurred by $25.5 \%$, followed by Fusarium solani by $19.0 \%$, and then Macrophomina phaseolina and Alternaria alternata by with 15.4 and $13.1 \%$, respectively, and the lowest pathogen occurred was Fusarium moniliforme by $11.8 \%$.

\section{Growth characteristics of faba bean} varieties

Seed inoculation of both faba bean varieties (i.e., Giza 429 and Giza 40) with a mixture of phosphorein + microbein at a ratio of $1: 1$ significantly increased all tested growth traits (i.e., shoot length, number of branches plant ${ }^{-1}$, leaf area plant ${ }^{-1}$, shoot fresh weight and shoot dry weight plant ${ }^{-1}$ ) compared to the individual inoculations (phosphorein or microbein), which in turn significantly increased these growth characteristics compared to the control; seeds without bio-fertilizers (Table 3).

The combined (phosphorein+microbein) was the best treatment, increasing the above growth characteristics by $74.1,37.6,53.2$, 92.7 and $89.7 \%$, respectively for Giza 429 , and by $82.7,54.25,60.0,97.0$ and $90.6 \%$, respectively for Giza 40 compared to the control.

For varieties, there was significant growth characteristics increases in Giza 429 compared to those in Giza 40.

\section{Physio-biochemical attributes of faba bean varieties}

Plants generated from phosphorein+microbein bio-fertilized seeds of both faba bean varieties showed significant increases in all physiobiochemical attributes (i.e., relative water content; RWC, membrane stability index; MSI, the contents of total soluble sugars; TSS, free proline, proteins, chlorophyll "a", chlorophyll "b" and total carotenoids) compared to those obtained from plants generated from phosphorein or microbein biofertilized seeds, which in turn significantly exceeded those obtained from the control plants that generated from untreated seeds (Table 4 and 5). The best treatment was phosphorein+microbein combined application that increased $\mathrm{RWC} \%$ by $47.4 \%$, MSI\% by $32.9 \%$, TSS content by $60.4 \%$, free proline content by $79.6 \%$, protein content by $90.3 \%$, chlorophyll "a" content by $72.6 \%$, chlorophyll "b" content by $67.9 \%$, and total carotenoids content by $78.8 \%$ for Giza 429 , and increased these parameters by $50.9,34.2,66.5,81.0$, $47.3,77.2,72.3$ and $77.8 \%$, respectively for Giza 40 compared to those of the control. Giza 429 showed significant higher values of physio-biochemical attributes than those of Giza 40.

\section{Nutrient status of faba bean varieties}

Phosphorein+microbein combined treatment for seeds of both faba bean varieties showed significant increases in the contents of $\mathrm{N}, \mathrm{P}$, $\mathrm{K}^{+}$, and $\mathrm{Ca}^{2+}$, while revealed significant reductions in the content of $\mathrm{Na}^{+}$compared to the individual treatment of phosphorein or microbein that in turn significantly exceeded the control (Table 6).

The combined phosphorein+microbein seed inoculation as the best treatment increased the $\mathrm{N}, \mathrm{P}, \mathrm{K}^{+}$, and $\mathrm{Ca}^{2+}$ contents by $56.8,81.1,69.1$ and $55.1 \%$, respectively for Giza 429 , and by $60.4,51.7,65.7$ and $55.3 \%$, respectively for Giza 40 while.

In contrast, the content of $\mathrm{Na}^{+}$was reduced 46.8 and $40.8 \%$ in Giza 429 and Giza 40, respectively by the best combined treatment compared to those of the control. The faba bean variety of Giza 429 collected higher macro-nutrient contents and lower $\mathrm{Na}^{+}$content than those collected by Giza 40 variety. 
Yield and its components of faba bean varieties

The combined phosphorein+microbein inoculation for faba bean seeds of both varieties significantly increased faba bean yield and its components (i.e., number of pods plant $^{-1}$, number of seeds pod ${ }^{-1}$, average 100dry seed weight, dry seed yield plant ${ }^{-1}$ and per $\mathrm{ha}^{-1}$ ) compared to the individual phosphorein or microbein treatment, which in turn significantly surpassed the control (Table 7). The increases in the yield and its components by the combined phosphorein+microbein application as the best treatment were 78.6, $88.2,52.6,60.0$ and $54.5 \%$, respectively for Giza 429, and were 87.2, 93.6, 50.8, 60.6 and $53.8 \%$, respectively for Giza 40 compared to those of the control. Giza 429 variety conferred higher green yield and its components than those conferred by Giza 40 variety.

\section{Damping-off and root-rot diseases in faba bean varieties}

Plants developed from both Giza 429 and Giza 40 seeds inoculated by the combined phosphorein+microbein showed significant decreases in damping-off, root-rot diseases and disease severity, while showed significant increases in survival ratio compared to the individual phosphorein or microbein inoculation, which in turn exceeded the control plants developed from non-inoculated seeds (Table 8). The combined phosphorein+microbein was the best treatment, decreasing pre- and post-emergence damping-off, root-rot incidence and disease severity by $31.7,45.2,30.6$ and $53.3 \%$, respectively for Giza 429, and by 40.1, 41.7, 29.9 and $49.8 \%$, respectively for Giza 40 , and increasing survival ratio by 27.3 and $31.0 \%$ for Giza 429 and Giza 40, respectively compared to those of the control. The variety of Giza 429 showed higher survival ratio and lower pre- and post-emergence damping-off, root-rot incidence and disease severity than those shown by Giza 40 variety.

Decreasing the infection of faba bean by soilborne diseases and increasing its yield are important indicators to find out the effect of bio-fertilizers on improving soil and faba bean health. Effective approaches for improving plant performances using bio-fertilizers supplementations are highly requested because they are an acceptable approach for higher yield with good quality in addition to that they are eco-friend and safe substances. Our results show that either individual or combined inoculation of phosphorein and microbein for seeds conferred higher positive responses of all investigated parameters. Sustainable farming systems that imbedded certain practices are reported to reduce the dependency on the conventional farming systems such as chemical fertilization and pesticides, which became nowadays unpleasant from the point of view of preserving the environment from pollution, as well as maintaining the soil fertility status (Rekha et al., 2018; Saikia et al., 2018). Therefore, the essential need for alternative practices that ensure the environmental safety and soil sustainability has become a must. Bio-fertilization farming is one of the environmental technologies, including phosphorein and microbein bio-fertilizers to provide soil fertility and more resistance for plants growing under biotic stress such as soilborne diseases (Ellafi and Gadalla 2010; Simarmata et al., 2016).

The soil used for the current study has shown to be infested with many of the soil-borne diseases (Fig. 1; Table 2). Damping off and root rot fungal diseases have shown high percentages $(29.2 \%$ as a mean of the two studied seasons) in the investigated soil. However, application of phosphorein and/or microbein bio-fertilizers, as seed inoculations, 
markedly resulted in clear improvements of the growth characteristics and yield and its components of faba bean plants compared to the control; seed without any bio-fertilizer (Table 3). Moreover, combined phosphorein+microbein seed inoculation significantly exceeded the individual inoculations for these parameters.

These positive results could be explained based on the positive integrative roles of the two bio-fertilizers (e.g., the integrative action of various beneficial micro-organisms found in both bio-fertilizers) in providing growing plant by increased available nitrogen $(\mathrm{N})$, phosphorus $(\mathrm{P})$, potassium $\left(\mathrm{K}^{+}\right)$, and calcium $\left(\mathrm{Ca}^{2+}\right)$ (Table 6).

This may be attributed to the role of phosphorein in solubilizing the phosphates in the soil and the role of microbein in fixing $\mathrm{N}_{2}$ because it contains $\mathrm{N}_{2}$-fixing bacteria such as Azotobacter spp., Azospirillum spp., and Pseudomonas spp., and phosphate-dissolving bacteria such as Bacillus megaterium, as well as it contains photosynthetic bacteria (ElWakeil and El-Sebai 2007; Yao et al., 2010; Farahat et al., 2014). Phosphorein and microbein bio-fertilizers have gained, together, the best nutritional values due to that these bio-fertilizers contain a great number of microorganisms that provides $\mathrm{N}_{2}$ fixation either symbiotic or non-symbiotic, in addition to release of some macro-nutrients to be available to plant roots such as $\mathrm{P}$ and $\mathrm{K}^{+}$(Abd El-Ati and El-Hadidy 2013). The important characteristic of bio-fertilizer is that they excrete ammonia into the rhizosphere in the presence of root exudates.

The increase in plant $\mathrm{P}$ content might be due to the P-solubilizing potential of the isolates used in bio-fertilizer. This might be attributed to the production of organic acids, chelating Oxo-acids and solubilization of inorganic insoluble phosphates by microorganisms (Rekha et al., 2018). Bio-fertilizers also improve the availability of $\mathrm{K}^{+}$nutrient in soil. This may be due to the presence of potash releasing bacteria in the bio-fertilizer that release the soluble $\mathrm{K}^{+}$from K-bearing minerals. The mechanism of $\mathrm{K}$ releasing from potash-bearing minerals is by organic acids production, rapidly dissolving rocks and chelate silicon ions and leads to releasing $\mathrm{K}^{+}$ ions into the soil (Bennett et al., 1998).

In addition, microbes in bio-fertilizers release organic acids into the soil to decrease soil $\mathrm{pH}$ that is suitable to the availability of nutrients to plant roots.

Using bio-fertilizers, especially the integrative phosphorein+microbein for faba bean seeds conferred higher protein and soluble sugars contents (Table 3).

This result may be due to the increased content of $\mathrm{N}$ (Table 6) as essential nutrient for formation of amino acids (Agamy et al., 2012), as well as due to the increased soluble sugars, which use with $\mathrm{N}$ to synthesize amino acids for protein formation.

In addition, this integrative bio-fertilizers application induced increases in relative water content (RWC, membrane stability index (MSI), and free proline content (Table 3).

These realities may be due to certain features in bio-fertilizers, playing a very important role in its mode of action (Abd El-Ati and ElHadidy 2013). One of these is the stimulated increase in the $\mathrm{K}^{+}$content, playing a crucial role as an osmolyte in increasing water absorption that increase the cell water content, maintaining its membranes from toxic elements by dilution and consequently increase of MSI. Moreover, bio-fertilizers improve plant physiological properties that enhance water and plant relationships, thus plant growth and metabolism (Rakha and ElSaid 2013). 
Table.1 Mechanical and chemical analyses of the experimental soils of two seasons*

\begin{tabular}{|c|c|c|c|c|c|}
\hline \multirow{2}{*}{\multicolumn{2}{|c|}{ Properties }} & \multicolumn{2}{|c|}{ Season of $2017 / 2018$} & \multicolumn{2}{|c|}{ Season of $2018 / 2019$} \\
\hline & & $30 \mathrm{~cm}$ depth & $60 \mathrm{~cm}$ depth & $30 \mathrm{~cm}$ depth & $60 \mathrm{~cm}$ depth \\
\hline \multicolumn{6}{|c|}{ Mechanical } \\
\hline \multicolumn{2}{|c|}{ Sand $(\%)$} & 25.7 & 27.7 & 27.0 & 29.9 \\
\hline \multicolumn{2}{|c|}{ Silt (\%) } & 19.1 & 18.0 & 17.9 & 19.2 \\
\hline \multicolumn{2}{|c|}{ Clay (\%) } & 55.2 & 54.3 & 55.1 & 50.9 \\
\hline \multicolumn{2}{|c|}{ Soil texture } & \multicolumn{4}{|l|}{ Clay } \\
\hline \multicolumn{6}{|c|}{ Chemical } \\
\hline \multicolumn{2}{|c|}{$\operatorname{ECe}\left(\mathrm{dS} \mathrm{m}^{-1}\right)$} & 1.79 & 1.79 & 1.63 & 1.67 \\
\hline \multicolumn{2}{|c|}{ Organic matter (\%) } & 1.35 & 1.23 & 1.41 & 1.33 \\
\hline $\mathbf{N}$ & \multirow[t]{3}{*}{$\mathrm{mg} \mathrm{kg}^{-1}$} & 71.1 & 73.1 & 75.1 & 77.1 \\
\hline $\mathbf{P}$ & & 21.0 & 22.0 & 23.1 & 25.0 \\
\hline $\mathbf{K}$ & & 695 & 697 & 731 & 722 \\
\hline
\end{tabular}

*All analyses were done in the Central Lab of Soil, Water and Plant Analyses (Iso-17025), Faculty of Agriculture, Fayoum University, Fayoum 63514, Egypt.

Table.2 Natural infections (\%) by damping off and root rot fungal diseases shown on faba bean plants grown on borne diseases-infected soil in two seasons

\begin{tabular}{|l|l|l|l|l|l|l|l|}
\hline \multirow{2}{*}{$\begin{array}{l}\text { Season \& } \\
\text { plant age }\end{array}$} & \multicolumn{3}{|c|}{ Season of 2016/2017 } & \multicolumn{2}{|c|}{ Season of 2017/2018 } & Grand \\
\cline { 2 - 8 } & $\begin{array}{c}\text { 2 months } \\
\text { old }\end{array}$ & $\begin{array}{c}\mathbf{4} \text { months } \\
\text { old }\end{array}$ & Mean & $\begin{array}{c}\text { 2 months } \\
\text { old }\end{array}$ & $\begin{array}{c}\text { 4 months } \\
\text { old }\end{array}$ & Mean & mean \\
\hline Infections (\%) & 20.5 & 36.7 & 28.6 & 22.4 & 37.2 & 29.8 & 29.2 \\
\hline
\end{tabular}

Table.3 Response of growth characteristics of twoVicia faba varieties to combined application of phosphorein (Phrn) and microbein (Mibn) under borne diseases-infected soil conditions

\begin{tabular}{|c|c|c|c|c|c|c|}
\hline \multicolumn{2}{|c|}{ Treatments } & \multirow{2}{*}{$\begin{array}{l}\text { Shoot } \\
\text { length } \\
(\mathrm{cm})\end{array}$} & \multirow{2}{*}{$\begin{array}{l}\text { No. of } \\
\text { branches } \\
\text { plant }^{-1}\end{array}$} & \multirow{2}{*}{$\begin{array}{c}\text { Leaves area } \\
\text { plant }^{-1} \\
\left(\mathbf{d m}^{2}\right)\end{array}$} & \multirow{2}{*}{$\begin{array}{c}\text { Shoot } \\
\text { fresh } \\
\text { weight (g) }\end{array}$} & \multirow{2}{*}{$\begin{array}{l}\text { Shoot dry } \\
\text { weight (g) }\end{array}$} \\
\hline Variety & $\begin{array}{l}\text { Bio- } \\
\text { fertilizer }\end{array}$ & & & & & \\
\hline \multirow{5}{*}{$\begin{array}{l}\text { Giza- } \\
429\end{array}$} & Control & $34.0 \mathrm{c}$ & $13.3 \mathrm{c}$ & $11.3 \mathrm{c}$ & $43.2 c$ & $5.13 \mathrm{c}$ \\
\hline & Phrn & $57.0 \mathrm{~b}$ & $16.1 b$ & $15.1 b$ & $80.1 b$ & $9.03 \mathrm{~b}$ \\
\hline & Mibn & $55.2 b$ & $15.9 b$ & $15.9 b$ & $79.2 b$ & $8.27 \mathrm{~b}$ \\
\hline & Phrn+Mibn & $59.1 \mathrm{a}$ & $18.2 \mathrm{a}$ & $17.2 \mathrm{a}$ & $83.2 \mathrm{a}$ & $9.73 \mathrm{a}$ \\
\hline & Mean & $51.3 \mathrm{~A}$ & 15.9A & 14.9A & 71.4A & $8.04 \mathrm{~A}$ \\
\hline \multirow{5}{*}{$\begin{array}{l}\text { Giza- } \\
40\end{array}$} & Control & $31.2 \mathrm{c}$ & $11.0 \mathrm{c}$ & $10.0 c$ & 41.1c & $3.73 \mathrm{c}$ \\
\hline & Phrn & $54.0 \mathrm{~b}$ & $14.7 b$ & $14.2 \mathrm{~b}$ & $77.1 \mathrm{~b}$ & $7.89 \mathrm{~b}$ \\
\hline & Mibn & $51.1 \mathrm{~b}$ & $14.0 \mathrm{~b}$ & $14.1 \mathrm{~b}$ & $76.9 \mathrm{~b}$ & $7.03 \mathrm{~b}$ \\
\hline & Phrn+Mibn & $57.1 \mathrm{a}$ & $17.0 \mathrm{a}$ & $16.1 \mathrm{a}$ & $81.0 \mathrm{a}$ & $7.11 \mathrm{a}$ \\
\hline & Mean & 48.3B & 14.2B & $13.6 \mathrm{~B}$ & $69.0 \mathrm{~B}$ & 6.44 B \\
\hline
\end{tabular}

Mean values in the same column for each trait with the same lower small or upper bold-case letters are not significantly different by Duncan's Multiple Range Test at $P \leq 0.05$. 
Table.4 Response of physio-biochemical attributes of two Vicia faba varieties to combined application of phosphorein (Phrn) and microbein (Mibn) under borne diseases-infected soil conditions

\begin{tabular}{|c|c|c|c|c|c|c|}
\hline \multicolumn{2}{|c|}{ Treatments } & \multirow{2}{*}{$\begin{array}{l}\text { Relative } \\
\text { water } \\
\text { content } \\
(\%)\end{array}$} & \multirow{2}{*}{$\begin{array}{l}\text { Membrane } \\
\text { stability } \\
\text { index (\%) }\end{array}$} & \multirow{2}{*}{$\begin{array}{l}\text { Protein } \\
\text { (mg-1 }^{-1} \\
\text { DW) }\end{array}$} & \multirow{2}{*}{$\begin{array}{l}\text { Total } \\
\text { soluble } \\
\text { sugars } \\
\left(\mathrm{mg}^{-1} \mathrm{DW}\right)\end{array}$} & \multirow{2}{*}{$\begin{array}{l}\text { Free } \\
\text { proline } \\
\left(\mu \mathrm{g} \mathrm{g} \mathrm{g}^{-1} \mathrm{DW}\right)\end{array}$} \\
\hline Variety & Bio-fertilizer & & & & & \\
\hline \multirow{5}{*}{$\begin{array}{l}\text { Giza- } \\
429\end{array}$} & Control & $45.5 \mathrm{c}$ & $64.1 \mathrm{c}$ & $2.17 \mathrm{c}$ & $5.13 \mathrm{c}$ & $105.3 \mathrm{c}$ \\
\hline & Phrn & $64.2 \mathrm{~b}$ & $81.0 \mathrm{~b}$ & $3.25 \mathrm{~b}$ & $7.01 \mathrm{~b}$ & $171.2 \mathrm{~b}$ \\
\hline & Mibn & $63.9 \mathrm{~b}$ & $80.2 b$ & $3.23 \mathrm{~b}$ & $6.93 \mathrm{~b}$ & $170.2 b$ \\
\hline & Phrn+Mibn & $67.1 \mathrm{a}$ & $85.2 \mathrm{a}$ & $4.13 \mathrm{a}$ & $8.23 \mathrm{a}$ & $189.1 \mathrm{a}$ \\
\hline & Mean & $60.2 A$ & $77.6 \mathrm{~A}$ & $3.20 \mathrm{~A}$ & $6.83 \mathrm{~A}$ & $159.0 \mathrm{~A}$ \\
\hline \multirow{5}{*}{$\begin{array}{l}\text { Giza- } \\
40\end{array}$} & Control & $43.2 \mathrm{c}$ & $62.0 \mathrm{c}$ & $2.07 \mathrm{c}$ & $4.03 \mathrm{c}$ & $102.3 \mathrm{c}$ \\
\hline & Phrn & $63.0 \mathrm{~b}$ & $77.9 \mathrm{~b}$ & $3.01 \mathrm{~b}$ & $5.93 \mathrm{~b}$ & $167.3 b$ \\
\hline & Mibn & $62.1 \mathrm{~b}$ & $76.9 \mathrm{~b}$ & $2.97 \mathrm{~b}$ & $5.05 \mathrm{~b}$ & $166.2 b$ \\
\hline & Phrn+Mibn & $65.2 \mathrm{a}$ & $83.1 \mathrm{a}$ & $3.05 \mathrm{a}$ & $6.71 \mathrm{a}$ & $185.1 \mathrm{a}$ \\
\hline & Mean & 58.4B & 75.0B & $2.78 \mathrm{~B}$ & $5.43 \mathrm{~B}$ & 155.2 B \\
\hline
\end{tabular}

Mean values in the same column for each trait with the same lower small or upper bold-case letters are not significantly different by Duncan's Multiple Range Test at $P \leq 0.05$.

Table.5 Response of leaf photosynthetic pigments contents of two Vicia faba varieties to combined application of phosphorein (Phrn) and microbein (Mibn) under borne diseases-infected soil conditions

\begin{tabular}{|c|c|c|c|c|}
\hline \multicolumn{2}{|c|}{ Treatments } & \multirow{2}{*}{$\begin{array}{c}\text { Chlorophyll "a" } \\
\left(\mathrm{mg} \mathrm{g}^{-1} \text { FW }\right)\end{array}$} & \multirow{2}{*}{$\begin{array}{l}\text { Chlorophyll } \\
\text { "b" } \\
\left.\text { (mg g } \text { g }^{-1} \mathbf{F W}\right)\end{array}$} & \multirow{2}{*}{$\begin{array}{l}\text { Carotenoids } \\
\left(\mathrm{mg} \mathrm{g}^{-1} \mathrm{FW}\right)\end{array}$} \\
\hline Variety & Bio-fertilizer & & & \\
\hline \multirow{5}{*}{$\begin{array}{l}\text { Giza- } \\
429\end{array}$} & Control & $1.13 \mathrm{c}$ & $0.53 \mathrm{c}$ & $0.33 \mathrm{c}$ \\
\hline & Phrn & $1.43 \mathrm{~b}$ & $0.74 \mathrm{~b}$ & $0.47 \mathrm{~b}$ \\
\hline & Mibn & $1.41 \mathrm{~b}$ & $0.73 \mathrm{~b}$ & $0.46 \mathrm{~b}$ \\
\hline & Phrn+Mibn & $1.95 \mathrm{a}$ & $0.89 \mathrm{a}$ & $0.59 \mathrm{a}$ \\
\hline & Mean & $1.48 \mathrm{~A}$ & $0.72 \mathrm{~A}$ & $0.46 \mathrm{~A}$ \\
\hline \multirow{5}{*}{$\begin{array}{l}\text { Giza- } \\
40\end{array}$} & Control & $1.01 \mathrm{c}$ & $0.47 \mathrm{c}$ & $0.27 \mathrm{c}$ \\
\hline & Phrn & $1.29 \mathrm{~b}$ & $0.61 \mathrm{~b}$ & $0.39 \mathrm{~b}$ \\
\hline & Mibn & $1.27 \mathrm{~b}$ & $0.60 \mathrm{~b}$ & $0.39 \mathrm{~b}$ \\
\hline & Phrn+Mibn & $1.79 \mathrm{a}$ & $0.81 \mathrm{a}$ & $0.48 \mathrm{a}$ \\
\hline & Mean & $1.34 \mathrm{~B}$ & $0.56 \mathrm{~B}$ & $0.38 \mathrm{~B}$ \\
\hline
\end{tabular}

Mean values in the same column for each trait with the same lower small or upper bold-case letters are not significantly different by Duncan's Multiple Range Test at $P \leq 0.05$. 
Table.6 Response of macro-nutrients and sodium contents of two Vicia faba varieties to combined application of phosphorein (Phrn) and microbein (Mibn) under borne diseases-infected soil conditions

\begin{tabular}{|c|c|c|c|c|c|c|}
\hline \multicolumn{2}{|c|}{ Treatments } & \multirow{2}{*}{$\begin{array}{c}\mathbf{N}(\mathrm{mg} \\
\left.\mathrm{g}^{-1} \mathrm{DW}\right)\end{array}$} & \multirow{2}{*}{$\begin{array}{c}P(\mathrm{mg} \\
\left.\mathrm{g}^{-1} \mathrm{DW}\right)\end{array}$} & \multirow{2}{*}{$\begin{array}{c}\mathrm{K}^{+}(\mathrm{mg} \\
\left.\mathrm{g}^{-1} \mathrm{DW}\right)\end{array}$} & \multirow{2}{*}{$\begin{array}{l}\mathrm{Ca}^{2+}(\mathrm{mg} \\
\left.\mathrm{g}^{-1} \mathrm{DW}\right)\end{array}$} & \multirow{2}{*}{$\begin{array}{l}\mathrm{Na}^{+}(\mathrm{mg} \\
\left.\mathrm{g}^{-1} \mathrm{DW}\right)\end{array}$} \\
\hline Variety & Bio-fertilizer & & & & & \\
\hline \multirow{5}{*}{$\begin{array}{l}\text { Giza- } \\
429\end{array}$} & Control & $23.7 \mathrm{c}$ & $2.17 \mathrm{c}$ & $21.2 b$ & $7.11 \mathrm{c}$ & $7.95 \mathrm{a}$ \\
\hline & Phrn & $33.3 b$ & $3.05 \mathrm{~b}$ & $31.9 \mathrm{~b}$ & $9.79 \mathrm{~b}$ & $5.09 \mathrm{~b}$ \\
\hline & Mibn & $32.7 b$ & $3.03 \mathrm{~b}$ & $31.1 \mathrm{~b}$ & $9.21 \mathrm{~b}$ & $5.17 \mathrm{~b}$ \\
\hline & Phrn+Mibn & $37.1 \mathrm{a}$ & $3.93 \mathrm{a}$ & $35.8 \mathrm{a}$ & $11.03 \mathrm{a}$ & $4.23 \mathrm{c}$ \\
\hline & Mean & $31.7 \mathrm{~A}$ & $3.05 \mathrm{~A}$ & 30.0A & $9.29 \mathrm{~A}$ & $5.36 \mathrm{~B}$ \\
\hline \multirow{5}{*}{$\begin{array}{l}\text { Giza- } \\
40\end{array}$} & Control & $21.9 \mathrm{c}$ & $2.01 \mathrm{c}$ & $20.0 \mathrm{c}$ & $5.97 \mathrm{c}$ & $8.93 \mathrm{a}$ \\
\hline & Phrn & $31.0 \mathrm{~b}$ & $2.83 \mathrm{~b}$ & $27.9 \mathrm{~b}$ & $7.89 \mathrm{~b}$ & $6.61 \mathrm{~b}$ \\
\hline & Mibn & $30.1 b$ & $2.75 \mathrm{~b}$ & $27.0 \mathrm{~b}$ & $7.25 \mathrm{~b}$ & $6.91 \mathrm{~b}$ \\
\hline & Phrn+Mibn & $35.2 \mathrm{a}$ & $3.05 \mathrm{a}$ & $33.2 \mathrm{a}$ & $9.27 \mathrm{a}$ & $5.29 \mathrm{c}$ \\
\hline & Mean & $29.5 \mathrm{~B}$ & $2.66 \mathrm{~B}$ & 27.0B & $7.60 \mathrm{~B}$ & $6.69 \mathrm{~A}$ \\
\hline
\end{tabular}

Mean values in the same column for each trait with the same lower small or upper bold-case letters are not significantly different by Duncan's Multiple Range Test at $P \leq 0.05$.

Table.7 Response of yield and its components of two Vicia faba varieties to combined application of phosphorein (Phrn) and microbein (Mibn) under borne diseases-infected soil conditions

\begin{tabular}{|c|c|c|c|c|c|c|}
\hline \multicolumn{2}{|c|}{ Treatments } & \multirow{2}{*}{$\begin{array}{c}\text { No. of } \\
\text { pods } \\
\text { plant }^{-1}\end{array}$} & \multirow{2}{*}{$\begin{array}{c}\text { No. of } \\
\text { seeds } \\
\text { pod }^{-1}\end{array}$} & \multirow{2}{*}{$\begin{array}{c}\text { Average } \\
\text { 100-seed } \\
\text { weight (g) }\end{array}$} & \multirow{2}{*}{$\begin{array}{l}\text { Dry seed } \\
\text { yield } \\
\text { plant }^{-1}(g)\end{array}$} & \multirow{2}{*}{$\begin{array}{l}\text { Dry seed } \\
\text { yield ha } \\
\quad \text { (ton) }\end{array}$} \\
\hline Variety & Bio-fertilizer & & & & & \\
\hline \multirow{5}{*}{$\begin{array}{l}\text { Giza- } \\
429\end{array}$} & Control & $15.3 \mathrm{c}$ & $2.29 \mathrm{c}$ & $53.3 \mathrm{c}$ & $33.3 c$ & $1.91 \mathrm{c}$ \\
\hline & Phrn & $25.0 \mathrm{~b}$ & $3.73 \mathrm{~b}$ & $76.2 b$ & $50.2 b$ & $2.27 \mathrm{~b}$ \\
\hline & Mibn & $24.7 \mathrm{~b}$ & $3.65 \mathrm{~b}$ & $75.3 b$ & $49.1 b$ & $2.25 \mathrm{~b}$ \\
\hline & Phrn+Mibn & $27.3 \mathrm{a}$ & $4.31 \mathrm{a}$ & $81.3 \mathrm{a}$ & $53.3 \mathrm{a}$ & $2.95 \mathrm{a}$ \\
\hline & Mean & 23.1A & $3.50 \mathrm{~A}$ & $71.5 \mathrm{~A}$ & $46.5 \mathrm{~A}$ & $2.35 \mathrm{~A}$ \\
\hline \multirow{5}{*}{$\begin{array}{l}\text { Giza- } \\
40\end{array}$} & Control & $13.8 \mathrm{c}$ & $2.03 \mathrm{c}$ & $51.2 \mathrm{c}$ & $31.3 \mathrm{c}$ & $1.71 \mathrm{c}$ \\
\hline & Phrn & $21.9 b$ & $3.07 \mathrm{~b}$ & $73.9 \mathrm{~b}$ & $48.9 \mathrm{~b}$ & $2.11 \mathrm{~b}$ \\
\hline & Mibn & $21.0 \mathrm{~b}$ & $3.05 \mathrm{~b}$ & $73.9 \mathrm{~b}$ & $48.1 \mathrm{~b}$ & $2.08 \mathrm{~b}$ \\
\hline & Phrn+Mibn & $25.8 \mathrm{a}$ & $3.93 \mathrm{a}$ & $77.3 \mathrm{a}$ & $50.2 \mathrm{a}$ & $2.63 \mathrm{a}$ \\
\hline & Mean & $20.6 \mathrm{~B}$ & 3.02 B & 69.1B & 44.6 B & $2.13 \mathrm{~B}$ \\
\hline
\end{tabular}

Mean values in the same column for each trait with the same lower small or upper bold-case letters are not significantly different by Duncan's Multiple Range Test at $P \leq 0.05$. 
Table.8 Combined application of phosphorein (Phrn) and microbein (Mibn) influences on damping-off and root-rot diseases of two Vicia faba varieties grown under borne diseasesinfected soil conditions

\begin{tabular}{|c|c|c|c|c|c|c|}
\hline \multicolumn{2}{|c|}{ Treatments } & \multicolumn{2}{|c|}{ Damping off (\%) } & \multirow{2}{*}{$\begin{array}{c}\text { Root-Rot } \\
\text { Incidence } \\
(\%)\end{array}$} & \multirow{2}{*}{$\begin{array}{c}\text { Survival } \\
\text { Ratio }\end{array}$} & \multirow{2}{*}{$\begin{array}{l}\text { Disease } \\
\text { severity }\end{array}$} \\
\hline Variety & $\begin{array}{l}\text { Bio- } \\
\text { fertilizer }\end{array}$ & Pre & Post & & & \\
\hline \multirow{5}{*}{$\begin{array}{l}\text { Giza- } \\
429\end{array}$} & Control & $5.49 \mathrm{a}$ & $11.25 \mathrm{a}$ & $27.5 \mathrm{a}$ & $55.76 \mathrm{c}$ & $1.95 \mathrm{a}$ \\
\hline & Phrn & $4.41 \mathrm{~b}$ & $7.67 \mathrm{~b}$ & $23.3 \mathrm{~b}$ & $64.62 \mathrm{~b}$ & $1.19 \mathrm{~b}$ \\
\hline & Mibn & $4.43 \mathrm{~b}$ & $7.73 \mathrm{~b}$ & $23.1 \mathrm{~b}$ & $64.74 \mathrm{~b}$ & $1.23 \mathrm{~b}$ \\
\hline & Phrn+Mibn & $3.75 \mathrm{c}$ & $6.17 \mathrm{c}$ & $19.1 \mathrm{c}$ & $70.98 \mathrm{a}$ & $0.91 \mathrm{c}$ \\
\hline & Mean & $4.52 \mathrm{~B}$ & $8.21 \mathrm{~B}$ & 23.3B & 63.97 A & $1.32 \mathrm{~B}$ \\
\hline \multirow{5}{*}{$\begin{array}{l}\text { Giza- } \\
40\end{array}$} & Control & $6.53 \mathrm{a}$ & $12.43 \mathrm{a}$ & $28.4 \mathrm{a}$ & $52.64 \mathrm{c}$ & $2.65 \mathrm{a}$ \\
\hline & Phrn & $5.39 \mathrm{~b}$ & $8.65 \mathrm{~b}$ & $24.3 \mathrm{~b}$ & $61.66 \mathrm{~b}$ & $2.17 \mathrm{~b}$ \\
\hline & Mibn & $5.41 \mathrm{~b}$ & $8.71 \mathrm{~b}$ & $24.2 b$ & $61.68 b$ & $2.19 \mathrm{~b}$ \\
\hline & Phrn+Mibn & $3.91 \mathrm{c}$ & $7.25 \mathrm{c}$ & $19.9 \mathrm{c}$ & $68.94 \mathrm{a}$ & $1.33 \mathrm{c}$ \\
\hline & Mean & $5.31 \mathrm{~A}$ & $9.26 \mathrm{~A}$ & $24.2 \mathrm{~A}$ & 61.23B & $2.09 \mathrm{~A}$ \\
\hline
\end{tabular}

Mean values in the same column for each trait with the same lower small or upper bold-case letters are not significantly different by Duncan's Multiple Range Test at $P \leq 0.05$.

Fig.1 Percentage (as a mean of two seasons; 2016/2017 and 2017/2018) of fungi isolated from faba bean roots grown in the Experimental Farm of the Faculty of Agriculture, Fayoum University, Fayoum, Egypt

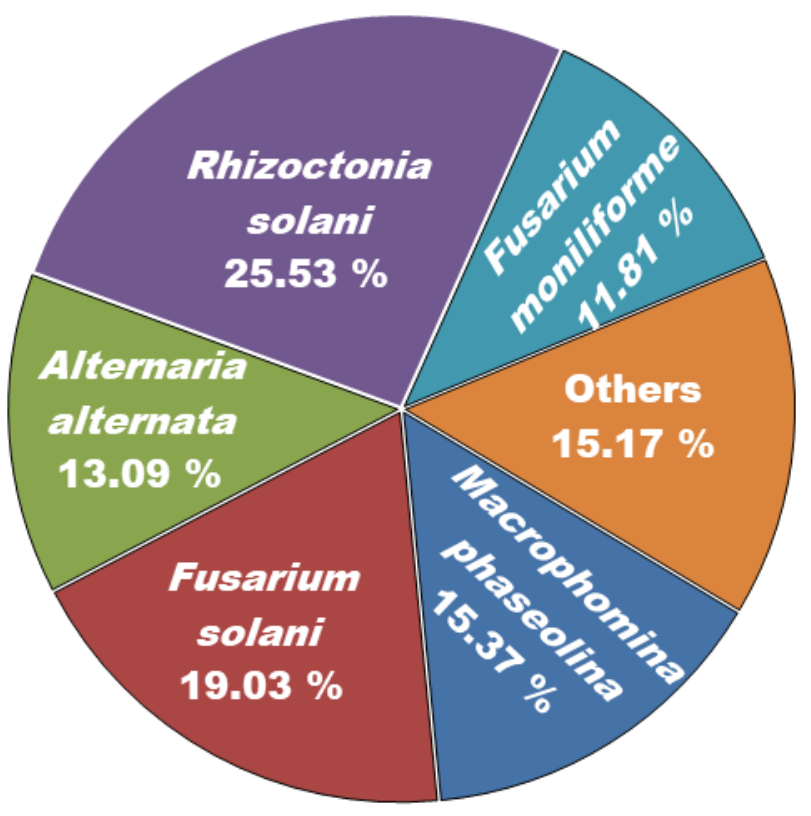


The significant increases occurred in the contents of chlorophyll "a", chlorophyll "b", and carotenoids in faba bean leaves by seed inoculation of both bio-fertilizers, especially the combined application compared with the untreated control (Table 5) may be attributed to the role of bio-fertilization in enhancement of $\mathrm{N}$ content (Table 6) as an important component for chlorophyll molecule formation (Agamy et al., 2012) and acceleration of chloroplasts differentiation. This explanation reflects in increasing photosynthetic process, conferring more photosynthates to support strong plant growth, especially root system to fight well the soilborne pathogens. In addition, bio-fertilizers have some hormonal effects for accelerating plant growth, escaping from the soil-borne pathogens.

In legumes, bio-fertilizers not only enhance the soil fertility but also improve the nodulation that play a role in a high suppression of soil-borne pathogens (Table 8). Besides, it releases some bio-fertilizers to encourage the uptake of nutrients by plant roots (Javaid and Mahmood, 2010). Moreover, it considers as organic manure containing $\mathrm{N}$, $\mathrm{P}, \mathrm{K}^{+}$, and many other essential nutrients, so it enhances retention of nutrients, consequently promotes growth of beneficial organisms that help plants to resist soil-borne diseases, producing more yields (Ross 2008). Biofertilizers have the ability to suppress the soilborne diseases such as Fusarium propagation which is a harmful microorganism that causes high disease problem in continuous cropping. Also, Fusarium pathogens encourage the promotion of harmful nematode increases. Thus, bio-fertilizers enhance quality and sustain soil environment by increasing antimicrobial activity of the soil. Application of bio-fertilizer, especially in integration of phosphorein and microbein can effectively increase the induced resistance of faba bean plants to soil borne pathogens and improve its productivity. It seems that the increase in the induced resistance plays a crucial role in improving plant health by suppressing the major soil-borne diseases. Where, biofertilizers suppress the pathogens; Rhizoctonia solani, Fusarium solani, Macrophomina phaseolina, Alternaria alternate, and others to protect faba bean plants and increase its productivity.

In contrast, without using bio-fertilization under the conditions of the biotic stress of the current study (the control) the virgin environment and human health are negatively affected and the probability of infection by and development of root-rot pathogens are occurred, leading to plant cell restriction, rapid cell mitosis, thinness of cell walls. These conditions could be perfect for the soil-borne diseases to generate its mass of injury ( $\mathrm{Xu}$ et al., 1996).

Our results show also that, the faba bean variety of Giza 429 showed more resistance to the mentioned soil-borne pathogens, conferring more growth and yield compared to the Giza 40 variety. Therefore, using the seed of Giza 429 variety and inoculating them with both bio-fertilizers (phosphorein and microbein) in integrative application considers as an effective strategy to increase faba bean yield significantly under the biotic stress of soil-borne diseases.

More specifically, after inoculation with biofertilizers and seedling growth, a symbiotic living occurs between plants and microorganisms found in bio-fertilizers. Fifteen genes have been up-regulated during symbiosis that identified as putative hexose transporters in L. bicolor (Bonfante and Genre 2010). Transporter gene up-regulation during symbiosis has indicated the action of useful compounds transportation like polyamines, amino acids, and oligopeptides through the symbiotic interface from one organism to other. Cysteine-rich proteins (MISSP7) of 
fungus play a crucial role as effectors and facilitators in the formation of symbiotic interfaces (Plett et al., 2011). Many auxin biosynthesis- and root morphogenesis-related genes have showed up-regulation during mycorrhizal colonization (Splivallo et al., 2009; Abdel-Raouf et al., 2012). Further, G. versiforme possesses inorganic phosphate $(\mathrm{Pi})$ transporters on its hyphae which help in the direct absorption of phosphate from the soil and a glutamine synthase gene was found in $G$. intraradice, which strengthens the possibility of nitrogen metabolism in fungal hyphe that can be transported later to the plant (Salvioli et al., 2012). Bioactive compounds so-called "Myc factors" in addition to "Nod factors" of Rhizobium have been suggested to be secreted by mycorrhiza and Rhizobium and perceived by host roots for the activation of signal transduction pathway or common symbiosis (SYM) pathway (Kosuta 2003; Roberts et al., 2013). This common symbiosis (SYM) pathway prepares the host plant to bring about changes at the molecular and anatomical level with the first contact of fungal hyphae. Heretofore, $\mathrm{Ca}^{2+}$ is supposed to be the hub of secondary messengers via $\mathrm{Ca}^{2+}$ spiking in the nuclear region of root hairs (Sieberer et al., 2009). In addition, it has been reported that Rhizobium leguminosarum biovar viciae can induce various genes in the plants like pea, alfalfa and sugar beet as evident from microarray studies (Ramachandran et al., 2011). Plant growthpromoting rhizobacteria (PGPR) produce IAA that, in turn, induces production of nitric oxide (NO). NO acts as a second messenger to trigger a complex signaling network leading to improved root growth and developmental process (Molina-Favero et al., 2007) to cope with the biotic stress like soil-borne pathogens. Expression of ENOD11 and many defense-related genes and root remodelling genes get up-regulated during entry. Consequently, this allows formation of a prepenetration apparatus or PPA (Bucher et al.,
2009). Many disease resistance genes that work via jasmonate/ethylene signaling as well as osmotic regulation via proline synthesis genes have been differentially expressed with Bacillus subtilis (UFLA285) induction (Baharlouei et al., 2011).

Various differentially expressed genes have been identified including metallothionein-like protein type 1, a NOD26-like membrane integral protein, ZmNIP2-1, a thionin family protein, an oryzain gamma chain precursor, stress-associated protein 1 (OsISAP1), probenazole-inducible protein PBZ1 and auxin and ethylene-responsive genes (BrusamarelloSantos et al., 2012). Expression of the defense-related proteins PBZ1 and thionins have been reported to get repressed in the rice- $\mathrm{H}$ seropedicae association, suggesting the modulation of plant defense responses during colonisation (Brusamarello-Santos et al., 2012). Among PGPR species, Azospirillum has been suggested to secrete gibberellins, ethylene, and auxins (Perrig et al., 2007). Some plant associated bacteria can also induce phytohormone synthesis in roots (Bent et al., 2001) supporting plants against biotic stress conditions. Rhizobium and Bacillus have been reported to synthesize IAA at different cultural conditions such as $\mathrm{pH}$, temperature and in the presence of agro waste as substrate (Sudha et al., 2012). Interestingly, the potential of PGPRs has been further improved by introducing genes involved in the direct oxidation (DO) pathway and mineral phosphate solubilization (MPS) into some useful strains of PGPRs. Gene encoding glucose dehydrogenase (gcd) involved in the DO pathway, as well as soluble form of gcd gene has been cloned and characterized from some PGPRs (Tripura et al., 2007; Sashidhar and Podile 2010). All of these mechanisms encourage plant growth strength and consequently cope effectively with biotic stress conditions such as soil-borne disease under study. 
This work can provide an acceptable explanation for the significant increase in faba bean growth, productivity and resistance to soil-borne diseases by application of biofertilizers, especially the combined application of phosphorein and microbein at a ratio of 1:1 to be the most appropriate bio-fertilization application under the biotic stress conditions (soil-borne diseases). To improve faba bean production under abovementioned stress conditions, the inoculant types should depend on the selection of effective bio-fertilizer. The best performing type was the combined phosphorein+microbein than their individuals. Therefore, we recommend using this combined application as commercial inocula for improving the production of faba bean and soil-borne diseases resistance.

\section{References}

A.O.A.C., 1995. Association of Official Analytical Chemists. Official Methods of analysis, $15^{\text {th }}$ Ed., Washington, DC, USA.

Abd El-Ati, A.A. and El-Hadidy, A.M.A. 2013. Improving productivity and control of soil borne diseases of broad bean by using different fertilization resources under reclaimed soil conditions. Egyptian Journal of Agronomy 35 (2): 135-153.

Abdel-Raouf, N., Al-Homaidan, A.A. and Ibraheem, I.B.M. 2012. Agricultural importance of algae. African Journal of Biotechnology 11: 11648-11658.

Abo El-Soud, A.A., Ragab, A.A., Mekhemar, G.A.A. and Mikhaeel, F.T. 2003. Response of faba bean to inoculation with $\mathrm{N}$-fixers and phosphate dissolving bacteria as influenced by different sources of phosphorus. Egyptian Journal of Applied Sciences 18 (1): 73-90.

Agamy, R.A., Mohamed, G.F. and Rady, M.M. 2012. Influence of the application of fertilizer type on growth, yield, anatomical structure and some chemical components of wheat (Triticum aestivum
L.) grown in newly reclaimed soil. Australian Journal of basic and Applied Sciences 6 (3): 561-570.

Ansari, M.W., Trivedi, D.K., Sahoo, R.K., Gill, S.S. and Tuteja, N. 2013. A critical review on fungi mediated plant responses with special emphasis to Piriformospora indica on improved production and protection of crops. Plant Physiology and Biochemistry 70: 403410.

Baharlouei, K., Pazira, E. and Solhi, M. 2011. Evaluation of Inoculation of plant Growth-Promoting Rhizobacteria on Cadmium. Singapore: International Conference on Environ. Sci. Technol., IPCBEE vol.6 IACSIT Press.

Bapaume, L. and Reinhardt, D. 2012. How membranes shape plant symbioses: signaling and transport in nodulation and arbuscular mycorrhiza. Frontiers in Plant Science 3: 223

Bates, L.S., Waldren, R.P. and Teare, I.D. 1973. Rapid determination of free proline for water stress studies. Plant and Soil 39: 205-207.

Bennett, P.C., Choi, W.J. and Rogera, J.R. 1998. Microbial destruction of feldspars. Mineral Management 8: 149-150.

Bent, E., Tuzun, S., Chanway, C.P. and Enebak, S. 2001. Alterations in plant growth and in root hormone levels of lodgepole pines inoculated with rhizobacteria. Canadian Journal of Microbiology 47: 793-800.

Bonfante, P. and Genre, A. 2010. Mechanisms underlying beneficial plant-fungus interactions in mycorrhizal symbiosis. Nature Communications 27: 1-48.

Brusamarello-Santos, L., Pacheco, F., Aljanabi, S., Monteiro, R., Cruz, L., Baura, V., Pedrosa, F., Souza, E. and Wassem, R. 2012. Differential gene expression of rice roots inoculated with the diazotroph Herbaspirillum seropedicae. Plant and Soil 356: 113-125.

Bucher, M., Wegmüller, S. and Drissner, D. 2009. Chasing the structures of small molecules in arbuscular mycorrhizal 
signalling. Current Opinion in Plant Biology 12: 500-507.

Burnett, H.L. and Hunter, B.B. 1972. Illustrated Genera of Imperfect Fungi. Burgess Pub. Co. Minneapolis, Minnesota, USA, 241 pp.

Chapman, H.D. and Pratt, P.F. 1978. Methods of Analysis for Soils, Plant and Waters. University of Callifornia Division of Agriculture Science. Priced publication, 4034, 50 and 169.

Ellafi, A.M., Gadalla, A. and Galal, Y.G.M. 2010. Biofertilizers in action: contributions of $\mathrm{BNF}$ in sustainable agricultural ecosystems. E-International Scientific Research Journal 3: 108.

El-Wakeil, N.E. and El-Sebai, T.N. 2007. Role of Bio fertilizer on Faba Bean Growth, Yield, and its Effect on Bean Aphid and the Associated Predators. Research Journal of Agriculture and Biological Sciences 3 (6): 800-807.

Eman, N.F., Bedeiwi, H. and Awad, N. 1993. Effect of phosphate solubilizing bacteria on growth of faba bean plant. Egyptian Journal of Applied Sciences 8 (6): 833846.

Farahat, M.M., El-Quesni, F.E.M., El-Khateeb, M.A., El-Leithy, A.S. and Hashish, K.I. 2014. Impact of combined chemical and biofertilizers on vegetative growth and chemical composition of Paulownia kawakamii seedlings. Middle East Journal of Agriculture Research 3 (4): 852-858.

Filion, M., St-Arnaul, M. and Jabaji-Hare, S.H. 2003. Quantification of Fusarium solani f. sp. phasolina in mycorrhizal bean plants and surrounding mycorrhizosphere soil using real time polymerase chain reaction and direct isolations on selective media. Phytopathology 93: 229-235.

Gilman, C.J. 1957. A manual of Soil Fungi. 2nd ed. Iowa. State Coliege Press, USA, pp. 450.

Gomez, K.A. and Gomez, A.A. 1984. Statistical Procedures for Agricultural Research, 2nd ed. John Wiley \& Sons, Singapore, p. 680 .

Habtegebriel, B. and Boydom, A. 2016. Integrated Management of Faba Bean Black Root Rot (Fusarium solani) through Varietal Resistance, Drainage and Adjustment of Planting Time. Journal of Plant Pathology and Microbiology 7: 363.doi:10.4172/21577471.1000363.

Irigoyen, J.J., Emerich, D.W. and Sanchez-Diaz, M. 1992. Water stress induced changes in the concentrations of proline and total soluble sugars in nodulated alfalfa (Medicago sativa) plants. Plant Physiology 8: 455-460.

Jackson, M.L. 1973. Soil Chemical Analysis, 1st ed. Prentice Hall of India Pvt. Ltd., New Delhi, India, pp. 61-73.

Javaid, A. and Mahmood, N. 2010. Growth, nodulation and yield response of soybean to bio fertilizers and organic manures. Pakistan Journal of Botany 42 (2): 863-871.

Khalil, S. and Labuschagne, I. 2002. Role of mycorrhizae, pathogens and weeds in sustainable pine forest management, soil biology and biochemistry section, national agricultural research centre, Islamabad-Pakistan. International Journal of Agriculture and Biology 4: 1.

Kosuta, S. 2003. Diffusible factor from arbuscular mycorrhizal fungi induces symbiosis-specific expression in roots of Medicago truncatula. Plant Physiology 131: 952-962.

Lichtenthaler, H.K. 1987. Chlorophylls and carotenoids: Pigments of photosynthetic biomembranes. Methods in Enzymology 148: $350-382$

Ling, N., Huang, Q., Guo, S. and Shen, Q. 2011. Paenibacillus polymyxa SQR-21 systemically affects root exudates of watermelon to decrease the conidial germination of Fusarium oxysporum f.sp. niveum. Plant and Soil 341: 485493.

Liu, J.Y., Maldonado-Mendoza, I., LopezMeyer, M., Cheung, F., Town, C.D. and Harrison, M.J. 2007. Arbuscular 
mycorrhizal symbiosis is accompanied by local and systemic alterations in gene expression and an increase in disease resistance in the shoots. Plant Journal 50: 529-544.

Medeiros, F.H.V., Souza, R.M., Medeiros, F.C.L., Zhang, H., Wheeler, T., Payton, P., Ferro, H.M. and Pare, P.W. 2011. Transcriptional profiling in cotton associated with Bacillus subtilis (UFLA285) induced biotic-stress tolerance. Plant and Soil 347: 327-337.

Mohammed, S.S. 2004. Integrated approach for rock phosphate sulfur combined with bio fertilization in sandy loam soil. Egyptian Journal of Applied Sciences 19 (2): 316333.

Molina-Favero, C., Mónica-Creus, C., LucianaLanteri, M., Correa-Aragunde, N., Lombardo, M.C., Barassi, A.C. and Lamattina, L. 2007. Nitric oxide and plant growth promoting rhizobacteria: Common features influencing root growth and development. Advances in Botanical Research 46: 1-33.

Neeraj, K.S. 2011. Organic amendments to soil inoculated arbuscular mycorrhizal fungi and Pseudomonas fluorescens treatments reduce the development of root-rot disease and enhance the yield of Phaseolus vulgaris L. European Journal of Soil Biology 47: 288-295.

Nelson, P.E., Toussoum, T.A. and Marasas, W.F. 1983. Fusarium spp. an illustrated manual for identification. The Pennsylvania University, Parl, USA, pp. 198.

Osman, A.Sh. and Rady, M.M. 2014. Effect of humic acid as an additive to growing media to enhance the production of eggplant and tomato transplants. The Journal of Horticultural Science and Biotechnology 89: 237-244.

Page, A.I., Miller, R.H. and Keeny, D.R. 1982. Methods of soil analysis. Part II, Chemical and Microbiological Methods 2nd ed. American Society of Agronomy, Madison, WI, USA, pp. 225-246.

Pandey, P.K., Yadav, S.K., Singh, A., Sarma,
B.K., Mishra, A. and Singh, H.B. 2012. Cross-species alleviation of biotic and abiotic stresses by the endophyte Pseudomonas aeruginosa PW09. Journal of Phytopathology 160: 532-539.

Perrig, D., Boiero, M.L., Masciarelli, O.A., Penna, C., Ruiz, O.A., Cassan, F.D. and Luna, M.V. 2007. Plant-growth promoting compounds produced by two agronomically important strains of Azospirillum brasilense, and implications for inoculant formulation. Applied Microbiology and Biotechnology 75: 1143-1150.

Plett, J.M., Kemppainen, M., Kale, S.D., Kohler, A., Legue, V., Brun, A., Tyler, B.M., Pardo, A.G. and Martin, F. 2011. A secreted effector protein of Laccaria bicolor is required for symbiosis development. Current Biology 21: 11971203.

Rady, M.M. 2011. Effect of 24-epibrassinolide on growth, yield, antioxidant system and cadmium content of bean (Phaseolus vulgaris L.) plants under salinity and cadmium stress. Scientia Horticulturae 129: 232-237.

Rady, M.M., Taha, R.S., Semida, W.M. and Alharby, H.F. 2017. Modulation of salt stress effects on Vicia faba L. plants grown on a reclaimed-saline soil by salicylic acid application. Romanian Agricultural Research 34: 175-185.

Rakha, M.K.A. and El-Said, E.M. 2013. Growth and yield of broad bean (Vicia faba L.) as affected by chemical and/or natural phosphorus with different bio fertilizer. Journal of Plant Production, Mansoura University 4 (12), 1857-1869.

Ramachandran, V.K., East, A.K., Karunakaran, R., Downie, J.A. and Poole, S.P. 2011. Adaptation of Rhizobium leguminosarum to pea, alfalfa and sugar beet rhizosphere investigated by comparative transcriptomics. Genome Biology 12: 106-109.

Rekha, D.L.M., Lakshmipathy, R. and Gopal, G.A. 2018. Effect of integrated use of biofertilizers, chemical fertilizers and 
farmyard manure on soil health parameters of pearl millet (Pennisetum glaucum L.). Journal of Soil Science and Plant Health 2 (2): 1000111 doi: 10.4172/JSPH.1000111.

Riedlinger, J., Schrey, S.D., Tarkka, M.T., Hampp, R., Kapur, M. and Fiedler, H.P. 2006. Auxofuran, a novel substance stimulating growth of fly agaric, produced by the mycorrhiza helper bacterium Streptomyces AcH 505. Applied and Environmental Microbiology 72: 3550-3557.

Roberts, N.J., Morieri, G., Kalsi, G., Rose, A., Stiller, J., Edwards, A., Xie, F., Gresshoff, P.M., Oldroyd, G.E., Downie, J.A. and Etzler, M.E. 2013. Rhizobial and mycorrhizal symbioses in Lotus japonicus require lectin nucleotide phosphohydrolase, which acts upstream of calcium signaling. Plant Physiology 161: 556-567.

Ross, H.M. 2008. "Managing Livestock Manure". Published by the Alberta Agriculture and Rural Development, Alberta, Available online at http//www1.agric.gov.ab.ca/\$department / deptdocs. nsf.

Saber, M.S.M., Abd El-Maksoud, H.K. and Khalafalla, M.A. 1983. The use of phosphate dissolving bacteria for increasing P-uptake and yield of Vicia faba L. cultivated in calcareous soil. Egyptian Journal of Microbiology (special issue): 41-46.

Saikia, J., Saikia, L., Phookan, D.B. and Nath, D.J. 2018. Effect of biofertilizer consortium on yield, quality and soil health of French bean (Phaseolus vulgaris L.). Legume Research International Journal 41 (5): 755-758.

Salvioli, A., Zouari, I., Chalot, M. and Bonfante, P. 2012. The arbuscular mycorrhizal status has an impact on the transcriptome profile and amino acid composition of tomato fruit. BMC Plant Biology 12: 44.

Sashidhar, B. and Podile, A.R. 2010. Mineral phosphate solubilisation by rhizosphere bacteria and scope for manipulation of the direct oxidation pathway involving glucose dehydrogenase. Journal of Applied Microbiology 109: 1-12.

Sieberer, B.J., Chabaud, M., Timmers, A.C., Monin, A., Fournier, J. and Barker, D.G. 2009. A nuclear-targeted cameleon demonstrates intranuclear $\mathrm{Ca}^{2+}$ spiking in Medicago truncatula root hairs in response to rhizobial nodulation factors. Plant Physiology 151: 1197-1206.

Simarmata, T., Hersanti, T.T., Fitriatin, B.N. and Setiawati, M.R.P. 2016. Application of Bioameliorant and Biofertilizers to Increase the Soil Health and Rice Productivity. HAYATI Journal of Biosciences 23: 181-184.

Splivallo, R., Fischer, U., Gobel, C., Feussner, I. and Karlovsky, P. 2009. Truffles regulate plant root morphogenesis via the production of auxin and ethylene. Plant Physiology 150: 2018-2029.

Sudha, M., Gowri, R.S., Prabhavati, P., Astapriya, P., Devi, S.Y. and Saranya, A. 2012. Production and optimization of indole-acetic-acid by indigenous micro flora using agro waste as substrate. Pakistan Journal of Biological Sciences 15: 39-43.

Taha, R.S., Mahdi, A.H.A. and Abd El-Rahman, H.A. 2016. Effect of biofertilizers as a partial substitute for mineral fertilizers on growth, anatomical structure, mineral elements and yield of wheat under newly reclaimed soil conditions. International Journal of Current Microbiology and Applied Sciences 5 (8): 458-469.

Toussaint, J.P., Kraml, M., Nell, M., Smith, S.E., Smith, F.A., Steinkellner, S., Schmiderer, H. and Novak, V. 2008. Effect of Glomus mosseae on concentrations of rosmarinic and caffeic acids and essential oil compounds in basil inoculated with Fusarium oxysporum f. sp. basilica. Plant Pathology 57: 1109-1116.

Tripura, C.B., Sudhakar Reddy, P., Reddy, M.K., Sashidhar, B. and Podile, A.R. 2007. Glucose dehydrogenase of a 
rhizobacterial strain of Enterobacter asburiae involved in mineral phosphate solubilization shares properties and sequence homology with other members of enterobacteriaceae. Indian Journal of Microbiology 47: 126-131.

Tromas, A., Parizot, B., Diagne, N., Champion, A. and Hocher, V. 2012. Heart of endosymbioses: transcriptomics reveals a conserved genetic program among arbuscular mycorrhizal, actinorhizal and legume-rhizobial symbioses. PLoS ONE 7: e44742.

Wood, I.M. and Myers, R.J.K. 1997. Food legumes in farming systems in the tropics and subtropics. In: Food Legume Improvement for Asian Farming systems. Wallis, E.S., Bythe, D.E., Eds. pp., 34-45. ACIAR. Canberra. Australia.

$\mathrm{Xu}$, H.L., Wang, R., Mridha, M.A.U. and
Umemura, U. 1996. Phytophthora resistance of tomato plants grown with EM-Bokashi. In: An earth saving revaluation (Terio Higaed.). Sunmark publishing Inc., Shinjuku-Ku, Tokyo, Japan.

Yao, L., Wu, Z., Zheng, Y. and Kaleem, I., Li, C. 2010. Growth promotion and protection against salt stress by Pseudomonas putida Rs-198 on cotton. European Journal of Soil Biology 46: 49-54.

Zhang, N., Kai, W., He, X., Li, S., Zhang, Z., Shen, B., Yang, X., Zhang, R., Huang, Q. and Shen, Q. 2011. A new bioorganic fertilizer can effectively control banana wilt by strong colonization with Bacillus subtilis N11. Plant and Soil 344: 87-97.

\section{How to cite this article:}

Ayman H. A. Mahdi, Mostafa M. Rady and Gomaa A. Abd El-Wahed. 2019. Integrative Application of Phosphorein and Microbein Improves Vicia faba (L.) Performance and Controls Soil-borne Diseases. Int.J.Curr.Microbiol.App.Sci. 8(10): 103-121. doi: https://doi.org/10.20546/ijcmas.2019.810.012 